\title{
Korelasi Peningkatan Kadar Neuron Spesific Enolase dengan Derajat Keparahan dan Luaran Fungsional Pasien Stroke Infark Aterotrombotik Akut
}

\author{
Neti Sri Wardiyani, Nurdjaman Nurimaba, Nani Kurniani \\ Bagian Ilmu Penyakit Saraf \\ Fakultas Kedokteran Universitas Padjadjaran \\ Rumah Sakit Hasan Sadikin, Bandung
}

\begin{abstract}
Abstrak
Pada stroke iskemik terjadi kerusakan neuronal serta penurunan glikolisis aerob akibat menurunnya kadar glukosa. Neuron specific enolase (NSE) yang terdapat pada jaringan neuronal banyak tidak terpakai sehingga kadarnya meningkat. Pada kerusakan neuronal serta gangguan membran sel, sawar darah otak terganggu sehingga NSE berdifusi kedalam ekstraselular dan cairan serebrospinal. Peningkatan kadar NSE serum juga berhubungan dengan volume infark dan luasnya kerusakan otak. Penelitian ini bertujuan untuk mengetahui peningkatan kadar NSE pasien stroke infark aterotrombotik akut, serta korelasinya dengan derajat keparahan stroke dan luaran fungsional. Rancangan penelitian adalah observational analytic dengan pendekatan kohort. Pasien stroke infark aterotrombotik fase akut sebagai kasus, sedangkan kontrolnya orang sehat. Penelitian dilakukan di Rumah Sakit Dr. Hasan Sadikin Bandung, mulai Februari sampai Agustus 2008. Pemeriksaan kadar NSE serum dan penilaian tingkat keparahan stroke berdasarkan National Institutes of Health Stroke Scale (NIHSS) dilakukan saat masuk rumah sakit, sedangkan luarannya dinilai pada hari ketujuh dengan indeks Barthel. Analisis yang digunakan adalah analisis bivariat dengan uji statistik Mann-Whitney dan uji Pearson. Dari 43 kasus dan 43 kontrol, didapatkan perbedaan kadar NSE serum yang bermakna rata-rata $=11,41[5,07] \mathrm{ng} / \mathrm{mL}$ berbanding $8,93[3,03] \mathrm{ng} / \mathrm{mL}(\mathrm{p}=0,019)$. Terdapat korelasi yang bermakna peningkatan kadar NSE serum dengan derajat keparahan yang dinilai berdasarkan skala NIHSS $(p=$ $0,024)$, juga dengan luaran fungsional $(\mathrm{p}=0,012)$. Nilai akurasi paling tinggi terdapat pada kadar NSE serum 12 $\mathrm{ng} / \mathrm{mL}$, dengan sensitivitas $42 \%$ dan spesifisitas $84 \%$. Kesimpulan dari penelitian ini adalah kadar NSE serum berkolerasi dengan derajat keparahan serta keluaran fungsional penderita stroke infark. [MKB. 2010;42(2):62-8].
\end{abstract}

Kata kunci: Kadar neuron specific enolase, stroke infark, NIHSS, Indeks Barthel

\section{Correlation of Serum Neuron Specific Enolase with Severity and Functional Outcome in Acute Atherothrombotic Infarction Stroke Patients}

\begin{abstract}
Neuronal damage and decreasing aerobic glicolysis process in ischaemic stroke are caused by lowering level of blood glucose. The amount of neuronal intrasitoplasmic glicolytic enolase enzyme, also known as neuron specific enolase, increases in blood circulation because it is not used anymore in damage neuron. So the mechanism failure in blood-brain barrier, as result of neuronal and cell membrane damage, causes NSE diffusion to extracellular and cerebrospinal fluid, then NSE level increases in blood serum and cerebrospinal fluid in acute cerebral infarction. Elevating NSE level is also connected with infarct volume and the extent of brain damage. The aim of this study was to evaluate connection between upgrading NSE serum level in acute atherothrombotic-stroke infarction patients, level of stroke incompatibility, and functional outcome. The method of study was observational analytic with kohort study. Subjects of study were divided into case group consisted of acute atherothrombotic-stroke infarction patients and control group consisted the healthy person. The data was collected in Hasan Sadikin Hospital between February
\end{abstract}

Korespondensi: dr. Neti Sri Wardiyani, Sp.S., RS. Juanda, Jl. Ir. H. Juanda No. 207, Kuningan Jawa Barat. Telp. 0232-876433, Hp: 08156087400,Email: neti_neuro@yahoo.com 
to August 2008. Evaluating patients was performed to get descriptions on NSE serum level, level stroke incompability measuring by NIHSS scoring at the first time entering the hospital, and Barthel index scoring at seventh day of treatment. This study was analyzed by bivariat analysis using Mann-Whitney statistic test and Pearson correlation test. There were 43 patients in each group. There was a significantly difference in NSE serum level on case group (mean was $11.41[5.07] \mathrm{ng} / \mathrm{mL}$ ) in comparison to those on control group (mean was 8.93 [3.03] $\mathrm{ng} / \mathrm{mL}$ ), $\mathrm{p}=0.019$. There was a significantly correlation between raising NSE serum level on case group and level of stroke incompatibility measuring by NIHSS scoring and also with functional outcome according to Barthel index scoring. The highest accuration value of NSE serum level was $12 \mathrm{ng} / \mathrm{mL}$ with $42 \%$ sensitivity and $84 \%$ specificity. The conclusion was neuron specific enolase serum level has correlation with severity and functional outcome in acute atherothrombotic infarction stroke patients. [MKB. 2010;42(2):62-8].

Key words: Neuron specific enolase serum level, stroke infarction, NIHSS, Barthel index

\section{Pendahuluan}

Stroke merupakan penyebab utama terjadinya gangguan fungsi atau disability, terutama pada usia pertengahan dan usia lanjut. Dua pertiga penderita stroke mengalami gangguan fungsi otak yang meliputi gangguan motorik, berbahasa, serta memori. Sekitar $80-85 \%$ dari seluruh kasus stroke disebabkan oleh iskemik, yang didasari oleh proses trombosis dan emboli. Pada stroke iskemik terjadi proses kerusakan neuronal berhubungan dengan hipoglikemia, akibat menurunnya aliran darah dan suplai glukosa sebagai substrat utama dalam memenuhi kebutuhan energi sel otak, dan menyebabkan terjadinya penurunan proses glikolisis aerob. ${ }^{1-3}$

Enolase (2-phospho-D-glycerate hydrolase atau enol+suffix-ase atau phosphopyruvate hydratase) merupakan bentuk dimerik isoenzim glikolitik, mengkonversi 2-phospho-D glycerate (2-PG) menjadi phosphoenolpyruvate (PEP) pada tahap kesembilan dalam proses glikolisis. Enolase juga mengkatalisasi reaksi sebaliknya bergantung pada konsentrasi substrat. Enzim ini ditemukan dalam seluruh jaringan dan organisme yang mempunyai kemampuan untuk melakukan proses glikolisis atau fermentasi glukosa. ${ }^{4-6}$

Neuron spesific enolase (NSE) merupakan bentuk neuronal dari enzim enolase glikolitik intrasitoplasma, dengan bentuk isoenzim $\gamma \gamma$ atau ENO2, yang dapat ditemukan pada jaringan otak, yaitu pada badan sel neuron dan akson, serta dalam sel neuroendokrin. Pada keadaan terjadinya kerusakan neuronal seperti pada stroke iskemik, banyak enzim enolase yang tidak terpakai karena penurunan proses glikolisis aerob, sehingga dalam sirkulasi kadarnya meningkat. Kerusakan neuronal serta gangguan membran sel, misalnya pada infark serebri, sawar darah otak terganggu dan terjadi desintegrasi sel-sel astroglial, sehingga NSE akan dengan mudah berdifusi kedalam ekstraselular dan cairan serebrospinal.

Adanya peningkatan kadar NSE dalam cairan serebrospinal dan serum darah penderita infark serebri akut, dapat dijadikan sebagai pertanda molekular dan ukuran dalam menilai kerusakan neuronal setelah terjadi proses iskemik otak. ${ }^{6-9}$

Peningkatan kadar NSE diduga berhubungan dengan volume infark dan luasnya kerusakan jaringan otak secara klinis terlihat dari derajat keparahan stroke. Untuk menilai tingkat atau derajat keparahan stroke digunakan penilaian dengan skala National Institutes of Health Stroke Scale (NIHSS). Peningkatan kadar NSE juga diduga mempunyai korelasi dengan luaran fungsional pasien pascastroke infark. Kerusakan otak yang luas akan memperburuk prognosis pasien secara fungsional. Salah satu penilaian luaran fungsional pasien pascastroke dengan menggunakan skala indeks Barthel. ${ }^{8-11}$

\section{Metode}

Penelitian ini dilakukan secara observational analytic dengan pendekatan kohort. Kelompok kasus adalah pasien stroke infark aterotrombotik serangan pertama pada fase akut, sedangkan kelompok kontrol adalah orang normal, yang memenuhi kriteria inklusi dan tidak termasuk kriteria eksklusi. Kriteria inklusi untuk kelompok kasus yang terdiri dari kasus stroke infark aterotrombotik yang didiagnosis pertama kali dengan pemeriksaan klinis dan CT scan kepala, usia 45-80 tahun, datang selambat-lambatnya 96 jam dari onset stroke, dirawat minimal selama 7 hari, selama perawatan pasien tidak mendapatkan neuroprotektan. Kriteria eksklusinya adalah 
penderita dengan penyakit sistemik berat, kanker paru-paru, pankreas, neuroblastoma, atau sel neuroendokrin lainnya, menderita cedera kepala, ensefalopati anoksia, ensefalitis, metastasis tumor ke otak, atau status epileptikus, serta mengalami penurunan kesadaran atau dirawat kurang dari 7 hari.

Untuk kelompok kontrol kriteria inklusinya adalah usia 45-80 tahun, tidak pernah mengalami stroke berdasarkan anamnesis dan pemeriksaan fisis, dengan kriteria eksklusi penyakit sistemik berat, kanker paru-paru, pankreas, neuroblastoma, atau kanker dari sel-sel neuroendokrin lainnya; cedera kepala, ensefalopati anoksia, ensefalitis, metastasis tumor ke otak, atau status epileptikus.

Penelitian dilakukan di Rumah Sakit Dr. Hasan Sadikin Bandung, mulai Februari sampai Agustus 2008 pada 43 kasus dan 43 kontrol. Dilakukan pemeriksaan kadar NSE serum dan penilaian NIHSS dilakukan pada saat masuk rumah sakit, kemudian dilakukan penilaian skala indeks Barthel pada hari ketujuh perawatan. Pada kelompok kontrol penilaian indeks Barthel dilakukan pada waktu yang bersamaan karena kelompok kontrol tidak dirawat.

Analisis statistik yang digunakan adalah analisis bivariat dengan uji Mann-Whitney dan uji korelasi Pearson.

\section{Hasil}

Gambar 1 menunjukkan distribusi usia dan jenis kelamin pada kelompok kasus dan kontrol. Pada kelompok kasus atau kontrol, proporsi laki-laki lebih banyak dibandingkan dengan perempuan, yaitu 28 laki-laki $(65,1 \%)$ dan 15 perempuan $(34,9 \%)$ pada kelompok kasus dan pada kelompok kontrol 26 laki-laki $(60,5 \%)$ dan 17 perempuan $(39,5 \%)$.

Usia rata-rata dalam penelitian ini adalah $61,91(9,05)$ tahun, dengan rentang usia 45-80 tahun dan proporsi terbanyak pada kelompok usia
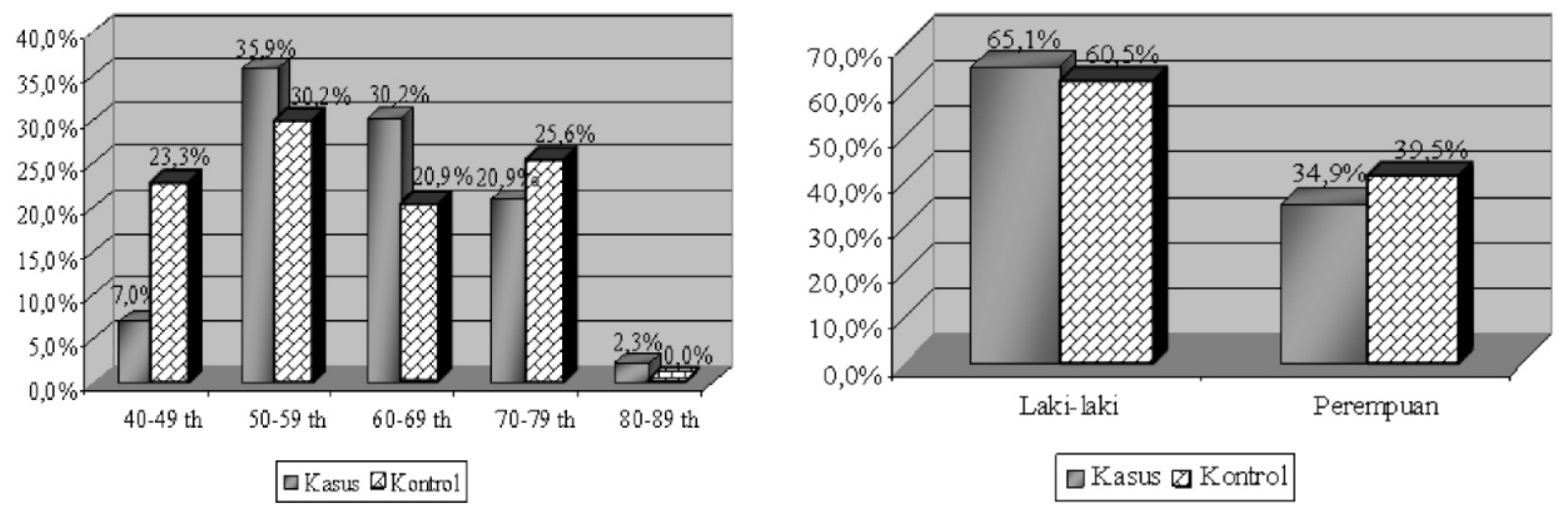

Gambar 1 Distribusi Usia dan Jenis Kelamin pada Kelompok Kasus dan Kelompok Kontrol Keterangan: $p=0,407$ untuk usia, nilai $p=0,500$ untuk jenis kelamin

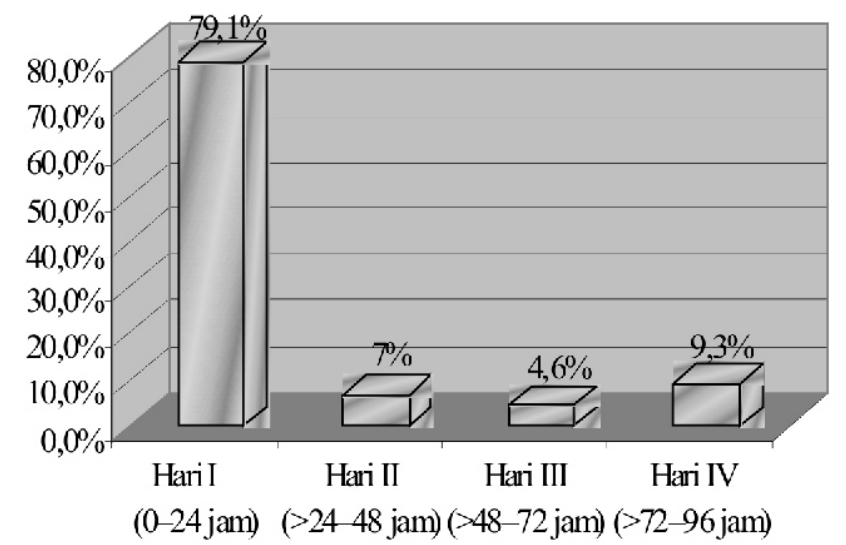

Gambar 2 Distribusi Waktu Pengambilan Sampel NSE 


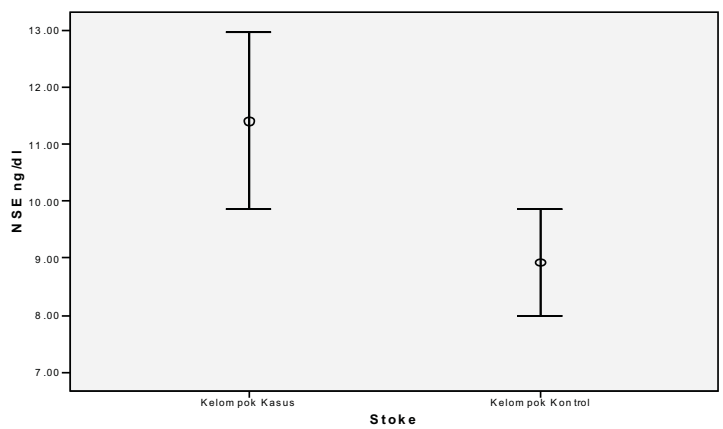

Gambar 3 Rata-rata Kadar NSE Serum pada Kelompok Kasus dan Kelompok Kontrol Keterangan:

Kadar kelompok kasus rata-rata NSE $=11,41[5,07] \mathrm{ng} / \mathrm{mL}$

Kadar kelompok kontrol rata-rata $=8,93[3,03] \mathrm{ng} / \mathrm{mL}, \mathrm{p}=0,019$

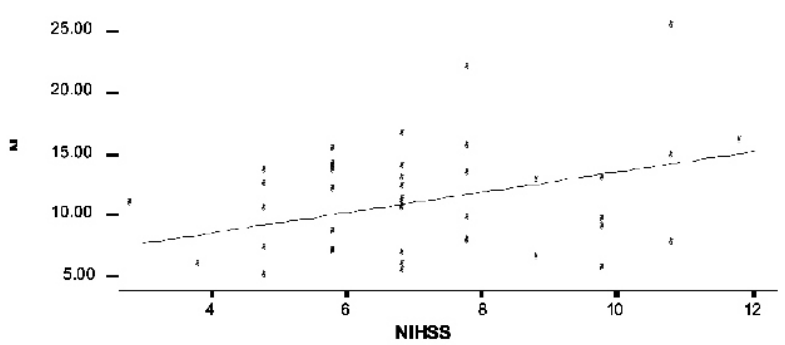

Gambar 4 Scatterplot Kadar NSE Serum dengan Nilai NIHSS Kelompok Kontrol

Keterangan:

$\mathrm{r}$ (nilai koefisien korelasi Pearson $)=+0,344$

$\mathrm{p}=0,024$

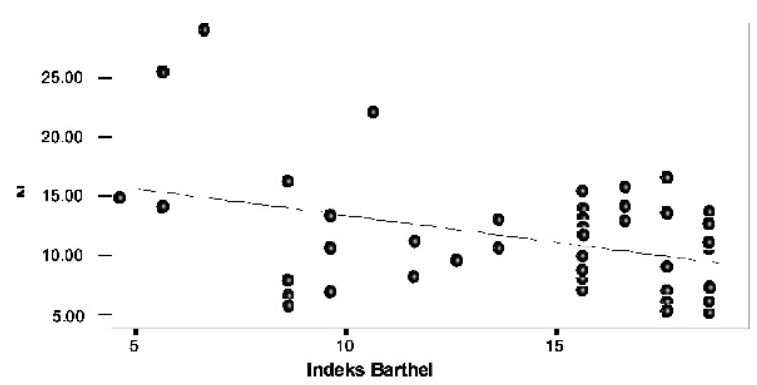

Gambar 5 Scatterplot Kadar NSE Serum dengan Nilai Indeks Barthel Kelompok Kontrol

Keterangan: $r=-0,380 ; p=0,012$

50-59 tahun sebanyak 17 orang $(35,9 \%)$. Usia rata-rata pada kelompok kontrol adalah 60,05 $(10,62)$ tahun dengan rentang usia 45-78 tahun dan proporsi terbanyak pada kelompok usia 50-59 tahun sebanyak 13 orang $(30,2 \%)$.

Gambar 2 menunjukkan waktu pengambilan sampel NSE serum pada kelompok kontrol dalam penelitian ini sebagian besar dilakukan pada hari pertama onset stroke.

Waktu rata-rata pengambilan sampel serum pada seluruh penderita dalam penelitian ini adalah
29,19 jam $(26,01)$ setelah kejadian awal atau setelah onset stroke.

Pada kelompok kasus kadar rata-rata NSE serum adalah $11,41[5,07] \mathrm{ng} / \mathrm{mL}$ dengan nilai paling rendah $(4,82 \mathrm{ng} / \mathrm{mL})$ dan yang tertinggi $28,75 \mathrm{ng} / \mathrm{mL}$, sedangkan pada kelompok kontrol rata-rata sebesar $8,93[3,03] \mathrm{ng} / \mathrm{mL}$, nilai terendah $4,20 \mathrm{ng} / \mathrm{mL}$, dan nilai tertinggi $15,52 \mathrm{ng} / \mathrm{mL}$, dengan nilai $p=0,019(p<0,05)$.

Berdasarkan uji statistik Pearson, ditemukan korelasi bermakna peningkatan kadar NSE serum 


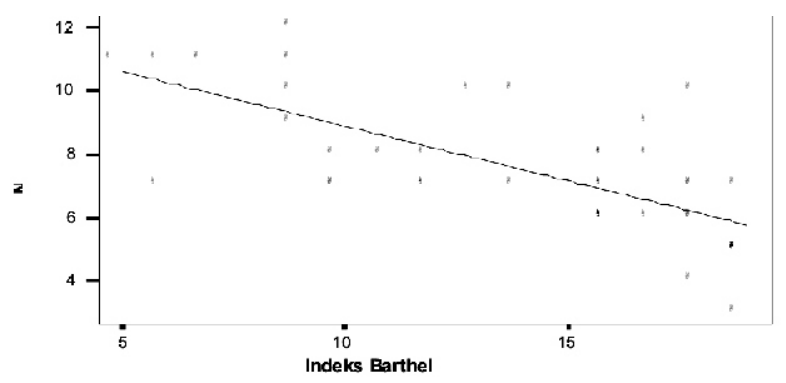

Gambar 6 Scatterplot Nilai Indeks Barthel dengan Nilai NIHSS Kelompok Kontrol

Keterangan: $r=-0,698 ; \mathrm{p}<0,001$

dengan penilaian derajat keparahan penderita stroke infark aterotrombotik berdasarkan skala NIHSS, dengan nilai p 0,024 dan nilai koefisien korelasi Pearson (r) sebesar $+0,344$. Hal ini menunjukkan hubungan yang berbanding lurus peningkatan kadar NSE serum dengan nilai NIHSS, semakin tinggi kadar NSE serum, maka semakin tinggi skala penilaian NIHSS.

Berdasarkan hasil uji statistik Pearson, juga ditemukan korelasi bermakna peningkatan kadar NSE serum dengan penilaian keluaran fungsional penderita berdasarkan skala indeks Barthel yang dinilai pada hari ketujuh perawatan, dengan nilai $p$ 0,012 dan koefisien korelasi Pearson (r) sebesar $-0,380$. Hal ini menunjukkan adanya hubungan berbanding terbalik antara peningkatan kadar NSE serum dan nilai indeks Barthel.

Terdapat hubungan yang berbanding terbalik antara nilai NIHSS yang diperiksa hari pertama perawatan dan nilai indeks Barthel penderita yang diperiksa pada hari ketujuh perawatan $(\mathrm{r}=-0,698)$.

\section{Pembahasan}

Gambar 1 menunjukkan bahwa usia rata-rata pada penelitian ini adalah $61,91(9,05)$ tahun, dengan rentang usia 45-80 tahun dan proporsi terbanyak pada kelompok usia 50-59 tahun sebanyak 17 orang $(35,9 \%)$. Usia rata-rata kelompok kontrol adalah 60,05 tahun $(10,62)$, dengan rentang usia 45-78 tahun dan proporsi terbanyak terdapat pada kelompok usia 50-59 tahun sebanyak 13 orang $(30,2 \%)$. Pada kelompok kasus maupun kontrol, proporsi laki-laki lebih banyak dibandingkan dengan perempuan, yaitu $28(65,1 \%)$ laki-laki dan $15(34,9 \%)$ perempuan pada kelompok kasus dan pada kelompok kontrol $26(60,5 \%)$ laki-laki dan $17(39,5 \%)$ perempuan. Berdasarkan hasil analisis statistik usia dan jenis kelamin tidak terdapat perbedaan yang bermakna antara kedua kelompok sehingga layak untuk diperbandingkan.

Gambar 2 menunjukkan distribusi waktu pengambilan sampel NSE serum. Waktu rata-rata pengambilan sampel serum dari seluruh penderita dalam penelitian ini adalah 29,19 jam $(26,01)$ setelah kejadian awal atau setelah onset stroke. Penelitian terhadap tikus menunjukkan bahwa peningkatan kadar NSE dalam sirkulasi darah mulai terlihat setelah 2 jam terjadinya proses iskemik. Penelitian Wu dkk. ${ }^{8}$ pada 38 kelompok penderita stroke infark dilakukan pemeriksaan kadar NSE serum secara serial pada hari ke-1, 2, 3, 4, dan hari ke-5 dari onset, menemukan kadar puncak peningkatan NSE serum pada 2,11 hari setelah onset infark. Penelitian Cunningham $\mathrm{dkk}^{10}$ menyatakan puncak kadar NSE serum terjadi dalam 96 jam pertama setelah infark serebral dan kadarnya tetap tinggi sampai 6 hari setelah infark.

Dalam penelitian ini salah satu kriteria inklusi kelompok kasus adalah pasien datang dalam 96 jam setelah onset, sehingga pemeriksaan kadar NSE serum didapatkan dalam 96 jam pertama setelah kejadian infark. Pemeriksaan NSE tidak dilakukan secara serial, hanya diperiksa satu kali yaitu saat pasien datang ke rumah sakit, sehingga tidak dapat ditentukan waktu puncaknya kadar NSE serum penderita.

Gambar 3 menunjukkan kadar NSE serum kedua kelompok. Uji statistik Mann-Whitney menunjukkan NSE serum yang bermakna $(\mathrm{p}=0,019)$. Pada penilitian ini kadar NSE serum penderita stroke infark fase akut sejalan dengan hasil penelitian $\mathrm{Wu}$ dkk. ${ }^{8}$ yaitu menemukan adanya peningkatan kadar NSE serum yang signifikan pada penderita stroke infark dibanding kelompok kontrol. Dari 38 penderita stroke infark sebagai kelompok kasus, ditemukan kadar NSE serum meningkat dengan kadar rerata 18,48 [16,6] $\mathrm{ng} / \mathrm{mL}$, sedangkan nilai rerata kadar NSE serum 
pada 27 orang sehat sebagai kelompok kontrol adalah $9,00[2,70] \mathrm{ng} / \mathrm{mL}$, dengan nilai $\mathrm{p}<0,001$. Seng-Hun dkk. ${ }^{8}$ menemukan peningkatan kadar NSE serum yang bermakna antara kasus dan kontrol, yang dilakukan pemeriksaan dalam 24 jam pertama setelah onset. Dari 81 penderita stroke infark, didapatkan nilai rata-rata kadar NSE serum 13,0 [5,4] ng/mL, sedangkan dari 77 kelompok kontrol ditemukan nilai rata-rata kadar NSE serum 6,3 $[1,6] \mathrm{ng} / \mathrm{mL}$, dengan nilai $\mathrm{p}<0,05$.

Gambar 4 menunjukkan korelasi NSE serum dengan NIHSS, dalam penelitian ini didapatkan hubungan berbanding lurus. Semakin tinggi kadar NSE serum penderita, maka semakin tinggi skala penilaian NIHSS. Penelitian Seng-Hun dkk. ${ }^{7}$ menunjukkan bahwa kadar NSE serum awal berkorelasi kuat dengan volume infark yang diketahui dari pemeriksaan MRI melalui penilaian volumetrik, dan berkorelasi dengan nilai NIHSS yang diperiksa saat pasien masuk rumah sakit $(\mathrm{r}=0,42 ; \mathrm{p}=0,002)$ serta dengan nilai NIHSS yang diperiksa 7 hari setelah onset serangan stroke $(\mathrm{r}=0,44 ; \mathrm{p}<0,001)$. Pilot study Lyden $\mathrm{dkk} .^{12}$ menunjukkan bahwa kadar puncak NSE serum yang dipantau sejak pasien masuk rumah sakit sampai dengan 7 hari kemudian, berkorelasi secara bermakna dengan skor NIHSS.

Gambar 5 menunjukkan korelasi antara kadar NSE serum dan luaran fungsional penderita yang dinilai berdasarkan skala indeks Barthel pada hari ke-7 perawatan. Hasil penelitian menunjukkan korelasi terbalik antara peningkatan kadar NSE serum dan nilai indeks Bartel. Semakin meningkat kadar NSE serum menggambarkan semakin luas kerusakan neuronal, maka nilai indeks Barthel penderita semakin rendah, yang menggambarkan luaran fungsional penderita semakin buruk. Pada penelitian ini juga mendapatkan bahwa penderita stroke infark aterotrombotik dengan kadar NSE serum terendah $(4,82 \mathrm{ng} / \mathrm{mL})$, mempunyai nilai indeks Barthel tertinggi, yaitu 19. Hal ini menunjukkan bahwa semakin rendah kadar NSE serum penderita, maka semakin sedikit kerusakan neuronal yang terjadi, sehingga prognosis pada penderita ini semakin baik.

Penelitian Wu dkk. ${ }^{8}$ menyimpulkan bahwa peningkatan dari kadar NSE serum dapat memperkirakan luaran fungsional pasien dengan menggunakan skala penilaian activity dailly living (ADL) pada 1 dan 3 bulan setelah onset stroke infark. Hasil penelitian mereka menunjukkan bahwa peningkatan kadar NSE serum mempunyai korelasi positif dengan volume infark $(\mathrm{p}<0,001)$, serta dapat memprediksi keluaran fungsional yang diperiksa dengan skala ADL, pada 1 bulan pertama setelah infark $(\mathrm{p}=0,022), 3$ bulan setelah infark $(\mathrm{p}=0,005)$, dan lebih bermakna pada penilaian luaran 6 bulan setelah infark $(\mathrm{p}<0,001)$.

Gambar 6 menggambarkan korelasi luaran fungsional yang diukur dengan indeks Barthel dengan derajat keparahan yang diukur dengan nilai NIHSS. Semakin tinggi hasil penilaian skala NIHSS menunjukkan semakin banyak defisit neurologi klinis, sedangkan nilai indeks Barthel semakin rendah menunjukkan prognosis dan luaran fungsional penderita semakin buruk. Analisis statistik berdasarkan uji Pearson, menunjukkan korelasi yang bermakna dengan nilai $p<0,001(p=0,000)$.

Penelitian ini memperoleh nilai akurasi yang paling tinggi (63\%) pada kadar NSE serum 12 $\mathrm{ng} / \mathrm{mL}$, dengan sensitivitas $42 \%$ dan spesifisitas $84 \%$. Penelitian Roine dkk. ${ }^{10}$ mendapatkan nilai sensitivitas $40 \%$ dan spesifisitas $98 \%$ dalam menilai kerusakan otak dengan kadar NSE serum dan mempuyai cut-off value $17 \mathrm{ng} / \mathrm{mL}$, sedangkan penelitian Zimmerman dkk. ${ }^{13}$ didapatkan bahwa kadar NSE serum meningkat ( $\geq 10 \mathrm{ng} / \mathrm{mL}$ ) pada $16 \%$ pasien stroke iskemik.

Penelitian ini menyimpulkan bahwa terdapat korelasi yang bermakna antara peningkatan kadar NSE serum dan derajat keparahan yang dinilai berdasarkan skala NIHSS dan luaran fungsional. Nilai akurasi paling tinggi terdapat pada kadar NSE serum $12 \mathrm{ng} / \mathrm{mL}$ dengan sensitivitas $42 \%$ dan spesifisitas $84 \%$.

\section{Daftar Pustaka}

1. Cellular Injury During Ischemic, in Pathogenesis and Pathophysiology, from Acute Ischemic stroke, New Concepts of Care (C) 1998-1999, Stroke Center, (diunduh 5 Feb 2008).

2. Calcium-dependent production of reactive oxygen species is involved in neuronal damage induced during glycolysis inhibition in cultured hippocampal neurons, Departamento de Neurociencias, Instituto de Fisiología Celular, Universidad Nacional Autónoma de México (UNAM), México D.F., México.

3. Acetoacetate protects hippocampal neurons against glutamate-mediated neuronal damage during glycolysis inhibition, Departamento de Neurociencias, Instituto de Fisiología Celular, 
Universidad Nacional Autónoma de México, CP 04510, AP 70-253, Mexico D.F., Mexico; (diunduh 4 March 2003).Tersedia dari: online 16 July 2003.

4. Schmechel D, Marangos PJ, Zis AP, Brightman M, Goodwin FK. Brain endolases as specific markers of neuronal and glial cells. Science. 1978;199: 313-5.

5. Evy Liswati. Protein S100B, neuron spesific enolase (NSE), myelin basic protein (MBP), dan heart-type fatty acid binding protein (H-FABP) sebagai penanda biokimiawi untuk stroke, Forum Diagnosticum 2006 \& Forum Diagnosticum Edisi Khusus 2005-2006, Laboratorium Klinik Prodia, September 2006

6. Lima JE, Takayanagui OM, Garcia LV, Leite JP. Use of neuron-specific enolase for assessing the severity and outcome of neurological disorders in patients, Braz J Med Biol Res. 2004 Jan;37(1):1926.

7. Seng-Hun O, Jin-Goo L, Sang-Jun N, Ji-Hyung P, Young-Chul C, Won-Joo K. Prediction of early clinical severity and extent of neuronal damage in anterior circulation infarction using the initial serum neuron-specific enolase level. Arch Neurol. 2003;60:37-41.

8. Wu YC, Zhao YB, Lu CZ, Qiao J, Tan YJ, Correlation between serum level of neuronspesifik enolase and long-term functional out- come after acute cerebral infarction: prospective study. Department of Neurology, Shanghai Jiao Tong University, Hong Kong Med J. 2004 Agt;10(4):251-4.

9. Cunningham RT, Watt M, Winder J. Serum neuronespecific enolase as an indicator of stroke volume. Eur J Clin Invest. 1996;26:298-303.

10. Roine RO, Somer H, Kaste M, Viinikka L, Karonen SL. Neurological outcome after out-ofhospital cardiac arrest: prediction by cerebrospinal fluid enzyme analysis. Arch Neurol. 1989;46: 753-6.

11. Fogel W, Krieger D, Veith M, Adams HP, Hund E, Storch-Hagenlocher B, dkk. Serum neuron-specific enolase as early predictor of outcome after cardiac arrest, Crit Care Med. 1997;25:1133-8.

12. Lyden PD, Mei Lu, Levine SR, Brott TG, Broderick J, the NINDS rtPA Stroke Study Group, A Modified National Institutes of Health Stroke Scale for Use in Stroke Clinical Trials, Preliminary Reliability and Validity, taken from (C) 2001 American Heart Association,Inc. (diunduh 15 Agst 2001).Tersedia dari http://www strokeaha. org.

13. Zimmermann-Ivol CG, Burkhard PR, Floch-Rohr JL. Fatty acid binding protein as a serum marker for the early diagnosis of stroke. Molecular Cellular Proteamics. 2004;3:66-72. 